Москва: Книга по Требованию, 2012. - 352 с. Текст: непосредственный.

\section{References}

1. Pshenitsa khlebopekarnaia. Tekhnicheskie usloviia: GOST 34702-2020. - Izdanie ofitsialnoe. IS «Tekhekspert: 6 pokolenie» Intranet, 2021. $14 \mathrm{~s}$.

2. Kincharov, A.I. Vliianie mineralnykh azotosoderzhashchikh udobrenii na produktivnost iarovoi miagkoi pshenitsy / A.I. Kincharov, E.A. Demina, O.S. Mullaianova, T.lu. Taranova. - Tekst: neposredstvennyi // International Journal of Humanities and Natural Sciences. - 2011. - No. 11. S. 22-26.

3. Mukina, L.R. Vliianie udobrenii na urozhainost iarovoi pshenitsy na seroi lesnoi pochve / L.R. Mukina, A.A. Shpedt. - Tekst: neposredstvennyi // Vestnik Altaiskogo gosudarstvennogo agrarnogo universiteta. - 2007. - No. 8. S. 9-12.

4. Abashev, V.D. Vliianie mineralnykh udobrenii na urozhainost i kachestvo zerna iarovoi pshenitsy Svecha / V.D. Abashev, F.A. Popov, E.N. Noskova, S.N. Zhuk. - Tekst: neposredstvennyi // Agrarnaia nauka Evro-Severo-Vostoka. - 2017. - No. 2. S. 35-39.

5. Antonova, O.I. Deistvie organomineralnykh udobrenii iz pometa na urozhainost i kachestvo zerna ozimoi i iarovoi pshenitsy, soderzhanie pitateInykh veshchestv i biogennost pochvy / O.I. Antonova, E.M. Komiakova, V.V. Kalpokas. - Tekst: neposredstvennyi // Vestnik Altaiskogo gosudar- stvennogo agrarnogo universiteta. - 2019. - No. 9. - S. 5-11.

6. Antonova, O.I. Effektivnost kompleksa sredstv khimizatsii (udobrenii, fungitsida i gerbitsidov) pri vozdelyvanii iarovoi pshenitsy sorta «Altaiskaia 92» v usloviiakh umerenno-zasushlivoi kolochnoi stepi / O.I. Antonova, S.I. Eshchenko, E.G. Eshchenko. - Tekst: neposredstvennyi // Vestnik Altaiskogo gosudarstvennogo agrarnogo universiteta. - 2004. - No. 4. - S. 6-10.

7. Tandelov, lu.P. Rol serosoderzhashchikh udobrenii $v$ optimizatsii mineralnogo pitaniia seroi lesnoi i dernovopodzolistoi pochvakh krasnoiarskoi podtaigi / lu.P. Tandelov, M.S. Patrina. - Tekst: neposredstvennyi // Vestnik Krasnoiarskogo GAU. 2011. - No. 11. - S. 40-45.

8. Aristarkhov A.N. Agrokhimiia sery / pod red. V.G. Sycheva. - Moskva: VNIIA, 2007. - 272 s.

9. Gaisin, I.A. Primenenie serosoderzhashchikh udobrenii v polevom sevooborote v usloviiakh seroi lesnoi pochvy / I.A. Gaisin, M.lu. Giliazov, A.S. Bilalova, F.Sh. Faskhutdinov, I.R. Suleimanov. - Tekst: neposredstvennyi // Agrokhimicheskii vestnik. 2009. - No. 5. - S. 3-5.

10. Tandelov, lu.P. Vliianie serosoderzhashchikh udobrenii na urozhai iarovoi pshenitsy / Iu.P. Tandelov, M.S. Bystrova. - Tekst: neposredstvennyi // Agrokhimicheskii vestnik. - 2007. - No. 4. - S. 29-31.

11. Dospekhov B.A. Metodika polevogo opyta (s osnovami statisticheskoi obrabotki rezultatov issledovanii) / B.A. Dospekhov. - Moskva, 2012. $352 \mathrm{~s}$.

ЭФФЕКТИВНОСТЬ ВОЗДЕЛЫВАНИЯ ЛЬНА МАСЛИЧНОГО, ОЗИМОЙ ПШЕНИЦЫ, МОГАРА В ПОЖНИВНОМ ПОСЕВЕ И ГОРОХА ПРИ АДАПТИВНОЙ СИСТЕМЕ ОСНОВНОЙ ОБРАБОТКИ ЧЕРНОЗЕМА ОБЫКНОВЕННОГО

\title{
THE EFFICIENCY OF CULTIVATING CROWN FLAX, WINTER WHEAT, FOXTAIL MILLET IN STUBBLE FIELD, AND FIELD PEA UNDER ADAPTIVE SYSTEM OF BASIC TILLAGE OF ORDINARY CHERNOZEM
}

Ключевые слова: вспашка, поверхностная, нулевая, лен, озимая пшеница, могар, горох, затраты, доход, органика.
Keywords: plowing, surface tillage, zero tillage, crown flax, winter wheat, foxtail millet (Setaria italica), field pea, costs, income, organic matter. 
Освоение ресурсосберегающих обработок почвы и технологий прямого посева (no-till) полевых культур заканчивается получением прибыли, если опирается на результаты научных исследований и практики, которых еще недостаточно по регионам. Учитывая это, в центральной зоне Краснодарского края в стационарном севообороте в 2013-2018 гг. изучали комплексное влияние вспашки 22-24 см (контроль), поверхностной 6-8 см и нулевой (гербицидной) обработки и культур звена севооборота на экономическую эфффективность производства и элементы почвенного плодородия. Среднегодовая температура воздуха в районе составляет $+12,1^{\circ} \mathrm{C}$, количество осадков - 614 мм. Почва чернозем обыкновенный, гумус в пахотном слое $3,8 \%, \mathrm{P}_{2} \mathrm{O}_{5}-22-28 ; \mathrm{K}_{2} \mathrm{O}-350-380 \mathrm{мг} /$ кг почвы (по Б.П. Мачигину). Учетная площадь делянок 5000 м², повторность 4-кратная. Повторность во времени 3-кратная. Культуры высевали сеялкой Рапид 600 с удобрением, возделывали с применением пестицидов и ростостимуляторов, убирали комбайном Claas Tucan. Установлено, что варианты обработки почвы влияли на урожайность льна масличного, озимой пшеницы, могара в пожнивном посеве и гороха, а также изменяли производственные затраты и условный чистый доход по культурам и звену севооборота. При технологии прямого посева за ротацию звена севооборота условный чистый доход составил 58,6 тыс. руб/га; расход горючего - 127 кг/га и затраты труда - 16,98 чел.-ч/га, что было на 5-43 и 11\% соответственно меньше, чем на контроле. Поверхностная обработка почвы также имела преимущество по указанным показателям. Отвальная вспашка снижала в 1,5-1,2 раза интенсивность накопления органического вещества по сравнению с прямым посевом (no-till) и поверхностной обработкой. Возделывание 4 культур в звене севооборота за 3 сельскохозяйственных года стабилизирует экономические показатели и почвенное плодородие. Разработанные технологии по оптимизации культур звена севооборота, постоянно востребованных рынком культур; адаптивным приемам основной обработки почвы и сохранению почвенного плодородия могут применяться землепользователями с аналогичными почвенными и климатическими условиями.

Полоус Виктор Стефанович, д.С.-х.Н., ООО «Аграрнопромышленная компания Кубань-Агро», Краснодарский край, Российская Федерация, e-mail: s.polous@list.ru.

Осауленко Сергей Николаевич, соискатель, ФГБОУ ВО Ставропольский ГАУ, г. Ставрополь, Российская Федерация, e-mail: s.polous@list.ru.
The development of resource-saving tillage and direct seeding technologies (no-till) of field crops end up making a profit when it is based on the results of research and practice but this is not the case in all regions. Taking this into account, in the central zone of the Krasnodar Region in the permanent crop rotation from 2013 through 2018, we studied the integrated effect of plowing $(22-24 \mathrm{~cm}$ - the control), surface tillage $(6-8 \mathrm{~cm})$ and zero tillage (herbicide treatment) and the crop in the rotation on the economic efficiency of production and elements of soil fertility. The average annual air temperature in the area is $+12.1^{\circ} \mathrm{C}$; the precipitation amount is $614 \mathrm{~mm}$. The soil is represented by ordinary chernozem; humus amount in the arable layer makes 3.8\%; $\mathrm{P}_{2} \mathrm{O}_{5}-22-28 \mathrm{mg} \mathrm{kg}$ of soil; $\mathrm{K}_{2} \mathrm{O}-350-380 \mathrm{mg}$ $\mathrm{kg}$ of soil (according to B.P. Machigin). The accounting area of the plots amounted to $5000 \mathrm{~m}^{2}$; fourfold plot replication; threefold temporal replication. The crops were sown with the Rapid 600 seeder with fertilizer application. Pesticides and growth promoters were used. The crops were harvested with a Claas Tucano combine harvester. It was found that the tillage variants affected the yields of crown flax, winter wheat, foxtail millet in stubble field, and field pea; and also changed the production costs and the conditional net income for crops and the course of the crop rotation. Under direct seeding technology, the conditional net income for the course of the crop rotation made 58.6 thousand rubles per ha; fuel consumption - $127 \mathrm{~kg}$ ha and labor costs - 16.98 man-hours per ha which was by $5 \%, 43 \%$ and $11 \%$, respectively, less than those in the control. Surface tillage also had an advantage in terms of these indicators. Moldboard plowing reduced the intensity of organic matter accumulation 1.5-1.2 times as compared to direct seeding (no-till) and surface tillage. The cultivation of 4 crops in a course of the crop rotation for 3 agricultural years stabilizes economic indicators and soil fertility. The developed technologies for crop optimization in a rotation (the crops in constant demand by the market); adaptive methods of basic tillage; preservation of soil fertility may be used by land users with similar soil and climatic conditions.

\section{Введение}

В Краснодарском крае полевые культуры возделываются на площади до 3,7 млн га в различных почвенно-климатических зонах [1].

В последние годы экономическая эффрективность сельхозпроизводства ограничена не только неустойчивыми валовыми сборами зерна,
Polous Viktor Stefanovich, Dr. Agr. Sci, OOO "Agrarnopromyshlennaya kompaniya Kuban-Agro", Krasnodar Region, Russian Federation, e-mail: s.polous@list.ru.

Osaulenko Sergey Nikolaevich, applicant for a degree, Stavropol State Agricultural University, Stavropol, Russian Federation, e-mail: s.polous@list.ru. технических и кормовых культур, высокими затратами на их производство, но и другими причинами, главными из которых являются: разрушение почвенной структуры [2], изменение биологической активности почвы [3], снижение органического вещества и физических характеристик [4] под влиянием климатических и других 
факторов. Дополнительные вложения на приобретение больших количеств минеральных удобрений $[5,6]$ и пестицидов [7] не всегда обеспечивают их окупаемость.

Увеличение доходов от земледелия и растениеводства возможно на основе внедрения севооборота или его звена, культуры которого обеспечивают высокие урожаи, в складывающихся погодных условиях, постоянно востребованы рынком, при высокой их стоимости; а также ежегодно обеспечивают положительный баланс гумуса почвы. Достижение этой цели невозможно без освоения ресурсосберегающих приемов [8] и технологии прямого посева полевых культур $[9,10]$. С целью получения новых научных и производственных знаний по указанным проблемам экономики и земледелия впервые проводились исследования в центральной зоне Краснодарского края. Перед закладкой опыта имелись публикации по эффеективности возделывания отдельных культур. Вообще отсутствовали данные для зернопропашного звена севооборота, с посевом пожнивной культуры на богаре, при различных способах и приемах основной обработки чернозема обыкновенного.

\section{Условия, материалы и методы}

Исследования проводились в стационарном севообороте в 2013-2018 гг. в центральной зоне Краснодарского края.

Среднегодовая температура воздуха в районе составляет $+12,1^{\circ} \mathrm{C}$, годовое количество осадков - 614 мм. Продолжительность безморозного периода - до 235 дней. Сумма температур свыше $5^{\circ} \mathrm{C}-2990-3000^{\circ} \mathrm{C}$. Почвы чернозем обыкновенный сверхмощный, среднесуглинистый. Содержание гумуса в пахотном слое $3,8 \%$, $\mathrm{P}_{2} \mathrm{O}_{5}$ - 22-28, $\mathrm{K}_{2} \mathrm{O}$ - 350-380 мг/кг почвы (по Б.П. Мачигину), $\mathrm{pH}-7,2$ солевой вытяжки. Учетная площадь делянок $5000 \mathrm{~m}^{2}$, повторность 4-кратная. Повторность во времени 3-кратная. В опытах культуры звена севооборота имели следующее чередование во времени: лен масличный - 2014, 2015, 2016 гг.; озимая пшеница и могар пожнивного посева - 2015, 2016, 2017 гг.; горох посевной - 2016, 2017, 2018 гг.

Схема опытов включала следующие варианты.

Для льна и пшеницы:

1) лущение стерни 8-10 см, отвальную вспашку 22-24 см, культивацию 8-10 см, прикатывание, культивацию до 6 см (контроль);
2) лущение стерни 6-8 см, повторное лущение 6-8 см, внесение гербицидов раундап 2 л/га и Банвел 0,1 л/га;

3) нулевая. Прямой посев культур. Внесение гербицидов: Раундап 2 л/га и банвел 0,1 л/га 3-кратно.

Для гороха посевного:

1) лущение стерни 8-10 см, отвальную вспашку 22-24 см, культивацию 8-10 см, прикатывание;

2) лущение стерни 6-8 см;

3) нулевая. Прямой посев культуры. Механические и химические обработки не проводились.

Для могара пожнивного посева:

1) лущение стерни 6-8 см и 2-кратное прикатывание.

Система удобрений и ухода за культурами звена севооборота.

Лен масличный при посеве внесено $\mathrm{N}_{6} \mathrm{P}_{26}$, в фазу елочки - гербицид Гербитокс-Л 1,5 л/га и ростостимулирующий состав (РС) Вермисол 1 л/га и НВ 1015 мм/га, гербицид Раундап 3 л/га при влажности семян льна 32-35\%.

Озимая пшеница: при посеве фон $\mathrm{N}_{12} \mathrm{P}_{52}$ и в качестве подкормки весной $\mathrm{N}_{68}$, для уничтожения сорняков Балерина 0,4 л/га и (PC) в тех же дозах, от болезней и вредителей использованы, соответственно, препараты «Колосаль Про» 0,5 л/га и «Фагот» - 0,15 л/га, а также РС в фазу колошения.

Могар: при полных всходах внесены $\mathrm{N}_{34}$, гербицид Балерина 0,3 л/га в фазу кущения совместно с (РС). При влажности семян $30-35 \%$ обработан Раундапом 3 л/га.

Горох: при посеве - $\mathrm{N}_{6} \mathrm{P}_{26}$, гербицид Базагран 3,5 л/га в фазу 4-5 листьев и РС, в начале цветения - инсектицид Фагот 0,15 л/га и РС, при влажности семян 30-35\% - десикант Реглон Супер 2 л/га.

Делянки льна масличного, озимой пшеницы и гороха посевного через 2-3 дня после посева (до всходов) обрабатывались Раундапом 2 л/га для уничтожения оставшихся сорняков и падалицы.

Посев осуществляли сеялкой для прямого посева Рапид 600.

Обработка гербицидами выполнялась опрыскивателем ОП-2000. Уборка урожая проводилась комбайном Клаас Тукан. Побочная продукция льна масличного и листостебельная масса могара укладывались в валки, тюковались и 
удалялись с вариантов 1-, 2-, 3-го опытного участка.

В опытах проводили расчет экономических показателей [11-13].

Статистическую обработку данных осуществляли по Б.А. Доспехову [14].

\section{Результаты и обсуждения}

При возделывании культур звена севооборота совокупные затраты определяли по технологическим картам хозяйства и корректировали с учетом сложившихся цен на оборотные и основные средства. В затратную часть включали стоимость семян, удобрений, пестицидов, дизельного топлива, а также прочие расходы, амортизацию, текущий ремонт технологических средств, аренду пашни, общехозяйственные и общепроизводственные расходы (табл. 1).

По вариантам основной обработки почвы оптимальные затраты в звене севооборота сложились при проведении поверхностной основной обработки под все культуры и составили 92720 руб/га, что было на 3\% ниже, чем на делянках с отвальной вспашкой и поверхностной под могар.
Использование технологии прямого посева культур и поверхностной под могар также снижало производственные затраты до 3040 руб/га по сравнению с контролем.

Затраты на удобрения и семена не изменялись по вариантам опыта и составляли, соответственно, 9370 и 5960 руб/га по звену севооборота.

Изменение способа и глубины основной обработки почвы заметно влияло на стоимость дизельного топлива при внесении пестицидов (особенно гербицидов), использованных в опыте. Если на контроле по звену севооборота было израсходовано ГСМ на сумму 6650 руб/га, пестицидов - 10150 руб/га, в том числе гербицидов - 7840 руб/га, то по технологии прямого посева и поверхностной под могар эти показатели изменились. Стоимость израсходованного топлива на 1 га уменьшилась на 43\%, а пестицидов увеличилась на $32 \%$, в том числе гербицидов на $47 \%$, или на 3670 руб/га.

Данные о производственных затратах и стоимости выращенной продукции позволили рассчитать условный чистый доход, себестоимость произведенной продукции и рентабельность возделывания культур по различным способом и приемам основной обработки почвы (табл. 2).

Таблица 1

\section{Производственные затраты при воздельвании культур в звене севооборота при различных способах и приемах основной обработки почвы, руб/2а}

\begin{tabular}{|c|c|c|c|c|c|c|c|}
\hline \multirow{3}{*}{ Культуры } & \multirow{3}{*}{ Всего } & \multicolumn{6}{|c|}{ В том числе } \\
\hline & & \multirow{2}{*}{ ГCM } & \multirow{2}{*}{ удобрения } & \multicolumn{2}{|c|}{ пестициды } & \multirow{2}{*}{ семена } & \multirow{2}{*}{ прочие } \\
\hline & & & & всего & в т.ч. гербициды & & \\
\hline \multicolumn{8}{|c|}{ Вспашка и поверхностная обработка } \\
\hline Лен & 23120 & 1680 & 1250 & 2010 & 1365 & 900 & 17280 \\
\hline Пшеница & 30660 & 1860 & 5470 & 1810 & 700 & 1600 & 19920 \\
\hline Могар & 10800 & 1350 & 1400 & 1070 & 825 & 260 & 6720 \\
\hline Горох & 31180 & 1760 & 1250 & 5260 & 4950 & 3200 & 19710 \\
\hline Итого & 95760 & 6650 & 9370 & 10150 & 7840 & 5960 & 63630 \\
\hline \multicolumn{8}{|c|}{ Поверхностная обработка под все культуры } \\
\hline Лен & 22010 & 1010 & 1250 & 2550 & 1910 & 900 & 16300 \\
\hline Пшеница & 29580 & 1180 & 5470 & 2360 & 1245 & 1600 & 18970 \\
\hline Могар & 11750 & 1350 & 1400 & 1070 & 825 & 260 & 7670 \\
\hline Гopox & 29380 & 1110 & 1250 & 5260 & 4950 & 3200 & 18560 \\
\hline Итого & 92720 & 4650 & 9370 & 11240 & 8930 & 5960 & 61500 \\
\hline \multicolumn{8}{|c|}{ Технология прямого посева и поверхностная } \\
\hline Лен & 22900 & 750 & 1250 & 3640 & 3400 & 900 & 16360 \\
\hline Пшеница & 30440 & 930 & 5470 & 3440 & 2335 & 1600 & 19000 \\
\hline Могар & 10340 & 1350 & 1400 & 1070 & 825 & 260 & 6260 \\
\hline Гopox & 28430 & 780 & 1250 & 5260 & 4950 & 3200 & 17940 \\
\hline Итого & 92110 & 3810 & 9370 & 13410 & 11510 & 5960 & 59560 \\
\hline
\end{tabular}




\section{Экономическая эффективность возделывания культур в звене севооборота при различных способах и приемах основной обработки почвы}

\begin{tabular}{|c|c|c|c|c|c|c|}
\hline Культуры & $\begin{array}{c}\text { Урожайность, } \\
\text { т/га }\end{array}$ & $\begin{array}{c}\text { Стоимость } \\
\text { валовой } \\
\text { подукции, } \\
\text { руб/га }\end{array}$ & Производственные \\
затраты, руб/га & $\begin{array}{c}\text { Себестоимость, } \\
\text { руб/ц }\end{array}$ & $\begin{array}{c}\text { Условный } \\
\text { чистый } \\
\text { доход, } \\
\text { руб/га }\end{array}$ & $\begin{array}{c}\text { Рентабельность, } \\
\%\end{array}$ \\
\hline \multicolumn{7}{|c|}{ Вспашка и поверхностная обработка } \\
\hline Лен & 1,84 & 42320 & 23120 & 1256 & 19200 & 83 \\
\hline Пшеница & 6,23 & 56070 & 30660 & 492 & 25410 & 83 \\
\hline Могар & $0,49 / 1,74$ & 14760 & 10800 & - & 3960 & 37 \\
\hline Горох & 4,01 & 44110 & 31180 & 778 & 12930 & 41 \\
\hline Итого & - & 157260 & 95760 & - & 61500 & - \\
\hline \multicolumn{7}{|c|}{ Поверхностная обработка под все культуры } \\
\hline Лен & 1,75 & 40250 & 22010 & 1258 & 18240 & 83 \\
\hline Пшеница & 6,48 & 58320 & 29580 & 456 & 28740 & 97 \\
\hline Могар & $0,50 / 1.78$ & 15120 & 11750 & - & 3370 & 29 \\
\hline Горох & 3,92 & 43120 & 29380 & 749 & 13740 & 47 \\
\hline $\begin{array}{l}\text { Итого по } \\
\text { варианту }\end{array}$ & 156810 & 92720 & - & 64090 & - \\
\hline \multicolumn{7}{|c|}{ Технология прямого посева и поверхностная обработка } \\
\hline Лен & 1,62 & 37260 & 22900 & 1414 & 14360 & 63 \\
\hline Пшеница & 6,05 & 54450 & 30440 & 503 & 24010 & 79 \\
\hline Могар & $0,51 / 1,73$ & 16590 & 10340 & - & 6250 & 60 \\
\hline Горох & 3,86 & 42460 & 28430 & 738 & 14030 & 49 \\
\hline Итого & - & 150760 & 92110 & - & 58650 & - \\
\hline
\end{tabular}

Стоимость валовой продукции по звену севооборота с вспашкой и поверхностей обработкой под могар составила 157260 руб., при поверхностной обработке опытных вариантов для возделывания льна масличного, озимой пшеницы, могара пожнивного посева и гороха данный показатель снизился на 450 руб/га, это связано с несущественным снижением урожайности льна и гороха. Однако более низкие производственные затраты на делянках с ресурсосберегающей основной обработкой почвы способствовали формированию условного чистого дохода, равного 64090 руб/га, что было на 4\% выше, чем на контроле, и на 9\% варианта с технологией прямого посева.

Применение технологии прямого посева культур было рентабельным. Так, по льну масличному этот показатель составил $63 \%$, озимой пшенице - 79; гороху посевному - 49\%. Однако это было ниже, чем на варианте с поверхностной обработкой почвы под культуры звена севооборота, в том числе на 20\% по льну масличному и 18\% озимой пшеницы.
Себестоимость 1 ц продукции зависела от производственных затрат и полученной урожайности по вариантам опыта.

В условиях рыночной экономики важным показателем экономической эффективности способов и приемов основной обработки почвы и выполнении других технологических операций является расход горючего и трудовых затрат (табл. 3).

В опытах при проведении технологических операций наиболее значительный расход горючего складывался в летне-осенний период. На делянках без механической обработки почвы расход горючего и затраты труда при уничтожении сорняков в летне-осенний период составил по звену севооборота, соответственно, 15,4 кг/га и 0,80 чел.-ч/га, многократно превысив контроль. Вместе с тем на этом варианте не было расхода дизельного топлива (кроме затрат на проведение основной обработки почвы под могар). Общий расход горючего здесь составил 127,0 кг/га при затратах труда 16,98 чел.-ч/га, что было ниже контроля на $11 \%$ и поверхностной обработки - на $3 \%$. 
Расход горючего и затрат труда

Таблица 3 при различных способах и приемах основной обработки почвы по культурам звена севооборота

\begin{tabular}{|c|c|c|c|c|c|c|}
\hline \multirow{3}{*}{ Культура } & \multirow{2}{*}{\multicolumn{2}{|c|}{ Всего }} & \multicolumn{4}{|c|}{ В том числе } \\
\hline & & & \multicolumn{2}{|c|}{ лущение и вспашка } & \multicolumn{2}{|c|}{ гербициды осенью } \\
\hline & топливо, кг/га & чел.-ч/га & топливо, кг/га & чел.-ч/га & топливо, кг/га & чел.-ч/га \\
\hline \multicolumn{7}{|c|}{ Вспашка и поверхностная обработка } \\
\hline Лен & 55,9 & 2,38 & 34,1 & 1,18 & 0,0 & 0,00 \\
\hline Пшеница & 62,1 & 3,46 & 34,1 & 1,18 & 0,0 & 0,00 \\
\hline Могар & 45,0 & 10,13 & 12,3 & 0,60 & 2,2 & 0,20 \\
\hline Гopox & 58,7 & 3,14 & 32,8 & 1,02 & & \\
\hline Итого & 221,7 & 19,11 & 113,3 & 3,98 & 2,2 & 0,20 \\
\hline \multicolumn{7}{|c|}{ Поверхностная обработка под все культуры } \\
\hline Лен & 33,8 & 1,84 & 12,0 & 0,64 & 3,3 & 0,20 \\
\hline Пшеница & 39,2 & 2,92 & 10,9 & 0,44 & 1,1 & 0,20 \\
\hline Могар & 45,0 & 10,34 & 12,3 & 0,60 & 2,2 & 0,20 \\
\hline Горох & 36,9 & 2,56 & 10,9 & 0,44 & 0,0 & 0,00 \\
\hline Итого & 154,9 & 17,66 & 46,1 & 2,12 & 6,6 & 0,60 \\
\hline \multicolumn{7}{|c|}{ Технология прямого посева и поверхностная обработка } \\
\hline Лен & 25,0 & 1,88 & 0,0 & 0,00 & 6,6 & 0,60 \\
\hline Пшеница & 31,0 & 2,88 & 0,0 & 0,00 & 6,6 & 0,60 \\
\hline Могар & 45,0 & 10,10 & 12,3 & 0,60 & 2,2 & 0,20 \\
\hline Гopox & 26,0 & 2,12 & 0,0 & 0,00 & 0,0 & 0,00 \\
\hline Итого & 127,0 & 16,98 & 12,3 & 0,60 & 15,4 & 0,80 \\
\hline
\end{tabular}

На варианте опыта с поверхностной основной обработкой под все культуры севооборота общий расход горючего был на уровне 154,9 кг/га и превышал вариант с прямым посевом на $18 \%$, а по затратам труда - на 0,68 чел.-ч/га.

Культуры звена севооборота, которые возделывали с удобрениями, пестицидами и ростостимуляторами, за ротацию накопили различное количество пожнивных и корневых остатков (ПКО): по вспашке - 31,12 т/га, поверхностной 31,55 и технологии прямого посева - 30,23 т/га. Из них, впоследствии, образовалось органическое вещество (гумус). На варианте опыта с технологией прямого посева прибавка составила $+2,19$ т/га, что превысило контроль на $30 \%$ и поверхностную обработку - на $14 \%$.

\section{Заключение}

1. Производственные затраты за ротацию звена севооборота по нулевой (гербицидной) обработке почвы составили 92120 руб/га и незначительно отличались от других вариантов опыта.

2. Технология прямого посева обеспечивала условный чистый доход 58650 руб/га, расход дизельного топлива 127,0 кг/га и затраты труда 16,98 чел.-ч/га, что было на 5, 43 и 11\% соответственно меньше, чем по вспашке. Поверхностная обработка почвы способствовала снижению расхода топлива до 154,9 кг/га, затрат труда до 17, 66 чел.-ч/га и получению наиболее высокого условного чистого дохода 64090 руб/га.

3. За ротацию культуры звена севооборота накапливали более 30 т/га пожнивных и корневых остатков, ставших основой для образования органического вещества. По технологии прямого посева его прибавка составила 2,19 т/га, что превысило контроль на $30 \%$ и поверхностную обработку - на 14\%.

\section{Библиографический список}

1. Сельское хозяйство Краснодарского края. 2016: статистический сборник / под редакцией Т. А. Кудряковой. - Краснодар, 2017. - 234 с. Текст: непосредственный.

2. Романенко, А. А. Кто поставит точку в войне с землей? / А. А. Романенко, П. П. Васюков. - Текст: непосредственный // Земледелие. 2006. - № 6. - С. 23-25.

3. Козлов, Е. М. Экологические проблемы в сельскохозяйственном производстве и некото- 
рые соображения о путях их преодоления / Е. М. Козлов. - Текст: непосредственный // Достижения и перспективы естественных и технических наук: материалы пятой Международной научно-практической конференции / Центр научного знания «Лотос». - Ставрополь, 2014. - № 5. - C. 4-15.

4. Тарханов, О. В. На пути к теории аграрного производства / О. В. Тарханов. - Москва: ВЭТУ, 2008. - 286 с. - Текст: непосредственный.

5. Дричко, В. Ф. Миграция химических элементов в биосфрере и экологосанитарные проблемы применения удобрений / В. Ф. Дричко. Ленинград: Ленинградский СХИ, 1990. - 31 с. Текст: непосредственный.

6. Минеев, В. Г. Экологические проблемы земледелия / В. Г. Минеев. - Москва: МГУ, 1988. - 485 с. - Текст: непосредственный.

7. Сокирко, В. П. Оздоровление почв Кубани от фузариозно-альтернариозной инфекции источник повышения урожая зерновых культур / В. П. Сокирко. - Текст: непосредственный // Труды Кубанского государственного аграрного университета. - Краснодар, 2015. - № 2 (59). C. 154-156.

8. Кошкин, П. Д. Эффрективность разных систем основной обработки почвы / П. Д. Кошкин. - Текст: непосредственный // Земледелие. 1997. - № 2. - C. 21-23.

9. Полоус, В. С. Адаптивная система основной обработки почвы и в зернопропашном севообороте на черноземе обыкновенном: монография / В. С. Полоус, В. Г. Шурупов. - Ростов-наДону: Изд-во СКНЦ ВШ ЮФУ АПСН, 2011. 163 с. - С. 133-140. - Текст: непосредственный.

10. Власова, О. И. Плодородие черноземных почв и приемы его воспроизводства в условиях Центрального Предкавказья: монография. Ставрополь: Агрус, 2014. - 306 с. - С. 256-258. Текст: непосредственный.

11. Методические рекомендации сравнительной оценки технологических и комплексов машин по энергитическому критерию. - Москва: ВИМ, 1987. - С. 6-21. - Текст: непосредственный

12. Методическое пособие по агроэнергитической и экономической оценке технологий и систем кормопроизводства. - Москва: ВНИИ кормов, 1995. - 174 с. - Текст: непосредственный.

13. Справочник экономиста-аграрника / под редакцией: Т. М. Васильевой, В. В. Маковецкого,
М. М. Максимова. - Москва: Колос, 2010. - 527 с. - Текст: непосредственный.

14. Доспехов, Б. А. Методика полевого опыта / Б. А. Доспехов. - Москва: Агропромиздат, 1985. - 351 с. - Текст: непосредственный.

\section{References}

1. Selskoe khoziaistvo Krasnodarskogo kraia. 2016. Statisticheskii sbornik / pod red. T.A. Kudriakovoi. - Krasnodar, 2017. - $234 \mathrm{~s}$.

2. Romanenko A.A. Kto postavit tochku v voine s zemlei? / A.A. Romanenko, P.P. Vasiukov // Zemledelie. - 2006. - No. 6. - S. 23-25.

3. Kozlov E.M. Ekologicheskie problemy $v$ selskokhoziaistvennom proizvodstve i nekotorye soobrazheniia o putiakh ikh preodoleniia // Dostizheniia i perspektivy estestvennykh i tekhnicheskikh nauk / Materialy piatoi mezhdunarodnoi nauchnoprakticheskoi konferentsii. - Tsentr nauchnogo znaniia, Lotos. - Stavropol, 2014. - S. 4-15.

4. Tarkhanov O.V. Na puti $k$ teorii agrarnogo proizvodstva. - Moskva: VETU, 2008. - $286 \mathrm{~s}$.

5. Drichko V.F. Migratsiia khimicheskikh elementov $\mathrm{v}$ biosfere i ekologo-sanitarnye problemy primeneniia udobrenii / V.F. Drichko. Leningrad: Leningradskii SKhl, 1990. - $31 \mathrm{~s}$.

6. Mineev V.G. Ekologicheskie problemy zemledeliia. - Moskva: MGU, 1988. - $485 \mathrm{~s}$.

7. Sokirko V.P. Ozdorovlenie pochv Kubani ot fuzariozno-alternarioznoi infektsii - istochnik povysheniia urozhaia zernovykh kultur // Trudy Kubanskogo GAU. - 2015. - No. 2 (59). - S. 154.

8. Koshkin P.D. Effektivnost raznykh sistem osnovnoi obrabotki pochvy // Zemledenie. - 1997. No. 2. - S. 21-23.

9. Polous V.S., Shurupov V.G. Adaptivnaia sistema osnovnoi obrabotki pochvy i $v$ zernopropashnom sevooborote na chernozeme obyknovennom. - Rostov-na-Donu: Izd-vo SKNTs VSh luFU, 2011. - S. 133-140.

10. Vlasova O.I. Plodorodie chernozemnykh pochv i priemy ego vosproizvodstva $v$ usloviiakh Tsentralnogo Predkavkazia. - Stavropol: Agrus, 2014. - S. 256-258.

11. Metodicheskie rekomendatsii sravnitelnoi otsenki tekhnologicheskikh i kompleksov mashin po energeticheskomu kriteriiu. - Moskva: VIM, 1987. S. 6-21.

12. Metodicheskoe posobie po agroenergeticheskoi i ekonomicheskoi otsenke tekhnologii i sistem kormoproizvodstva. - Moskva: VNII kormov, 1995. $-174 \mathrm{~s}$. 
13. Spravochnik ekonomista-agrarnika / pod red. T.M. Vasilevoi, V.V. Makovetskogo, M.M. Maksimova. - Moskva: Kolos, 2010. - 527 s.
14. Dospekhov B.A. Metodika polevogo opyta. - Moskva: Agropromizdat, 1985. - 351 s.

\section{БИОЛОГО-ХОЗЯЙСТВЕННАЯ ОЦЕНКА СОРТОВ ГОРОХА ПОСЕВНОГО И ПОЛЕВОГО ПРИ ВОЗДЕЛЫВАНИИ НА КОРМОВУЮ ПРОДУКТИВНОСТЬ В УСЛОВИЯХ ШЕБАЛИНСКОЙ ПОДЗОНЫ СРЕДНЕГОРНОЙ ЗОНЫ РЕСПУБЛИКИ АЛТАЙ}

\section{BIOLOGICAL AND ECONOMIC EVALUATION OF PISUM SATIVUM L. AND PISUM ARVENSE L. VARIETIES GROWN FOR FORAGE UNDER THE CONDITIONS OF THE SHEBALINO SUBZONE OF THE MID-MOUNTAIN ZONE OF THE REPUBLIC OF ALTAI}

Ключевые слова: сорт, горох, горох полевой (пелюшка), вегетационный период, урожайность, зеленая масса, сухое вещество, переваримый протеин, обменная энергия.

Для природно-климатических условий Шебалинской подзоны среднегорной зоны Республики Алтай на кормовую продуктивность на протяжении 2017-2019 гг. подбирались наиболее продуктивные укосные сорта гороха посевного и полевого (пелюшка). Самые высокорослые оказались сорта пелюшки Кормовая 50, Новосибирская 1 (139-148 см). Среди сортов гороха - Алтайский универсальный (124 см). Наиболее устойчивые к полеганию сорта гороха Аванс и пелюшки Кормовая 50 (3,6 балла). Лидерами по урожайности зеленой массы относительно контроля Аванс (18,0 т/га) стали сорта гороха Алтайский универсальный (+8,29 т/га), пелюшки - Кормовая 50 (+7,58 т/га), Николка (+7,96 т/га), Новосибирская 1 (+8,23 т/га). По сбору сухого вещества данные сорта превзошли контроль на 0,18-1,92 т/га. Высокой обеспеченностью 1 кормовой единицы переваримым протеином отмечены сорта пелюшки Николка и Новосибирская 1 - 157-171 г, у остальных сортов данный показатель находился в пределах 138-148 г. Урожайность сена производственных смешенных посевов в 2020 г.: овес Аргумент + горох Алтайский универсальный в соотношении (70х30\%) составила 5,48 т/га, при обеспеченности 1 кормовой единицы переваримым протеином 111 г; овес Аргумент + пелюшка Кормавая 50 - 5,86 т/га и 116 г соответственно. Смешанные посевы овса с данными сортами гороха и пелюшки позволяют получать сбалансированные по протеину корма.
Keywords: variety, Pisum sativum L., Pisum arvense L., growing season, yield, herbage, dry matter, digestible protein, metabolizable energy.

For the natural and climatic conditions of the Shebalino subzone of the mid-mountain zone of the Republic of Altai, the most productive mowing varieties of Pisum sativum $L$. and Pisum arvense $L$. were selected for forage production from 2017 through 2019. The varieties of Pisum arvense $L$. Kormovaya 50 and Novosibirskaya 1 were the tallest ones (139-148 cm); among Pisum sativum L. varieties - Altayskiy universalniy $(124 \mathrm{~cm})$. The varieties Avans (Pisum sativum L.) and Kormovaya 50 (Pisum arvense L.) were the most resistant to lodging (3.6 score points). The following varieties reached the largest herbage yields as compared to the control variety Avans (18.0 t ha): Pisum sativum $L$. Altayskiy universalniy (+8.29 t ha); Pisum arvense $L$. varieties Kormovaya 50 (+7.58 t ha), Nikolka (+7.96 t ha) and Novosibirskaya 1 (+8.23 tha). Regarding dry matter yield, these varieties exceeded the control by 0.18-1.92 tha. The varieties of Pisum arvense L. Nikolka and Novosibirskaya 1 had a high level of digestible protein per fodder unit (157$171 \mathrm{~g}$ ) while the other varieties had this value in the range of $138-148 \mathrm{~g}$. The hay yield of commercial mixed crops in 2020 was as following: oat variety Argument + Pisum sativum L. Altayskiy universalniy $(70 \% \times 30 \%)-5.48 \mathrm{t}$ ha; digestible protein per fodder unit - $111 \mathrm{~g}$; oat variety Argument + Pisum arvense $L$. variety Kormovaya $50-5.86$ tha and $116 \mathrm{~g}$, respectively. Mixed crops of oats with these varieties of Pisum sativum $L$. and Pisum arvense $L$. allow obtaining protein-balanced forages.
Бугаева Марина Владимировна, С.н.С., ФГБНУ «Федеральный Алтайский научный центр агробиотехнологий», г. Барнаул, Российская Федерация, e-mail: m.w.bugaeva@yandex.ru.
Bugayeva Marina Vladimirovna, Senior Staff Scientist, Federal Altai Scientific Center of Agro-Biotechnologies, Barnaul, Russian Federation, e-mail: m.w.bugaeva@ yandex.ru. 